\title{
TEOLOGICZNY I ANTROPOLOGICZNY WYMIAR OBRZĘDÓW CHRZCIELNYCH W KOŚCIELE IV WIEKU
}

W Kościele pierwszych wieków chrzest uważano za niezwykle ważne wydarzenie, zarówno w życiu tego, kto go przyjmował, jak i w całej wspólnocie Kościoła ${ }^{1}$. Dlatego też troszczono się, by przygotowanie do jego przyjęcia, jak i przeżywanie samej uroczystości, odbywało się świadomie, z głębokim poczuciem tego, co ma lub miało miejsce ${ }^{2}$. Katechumeni wprowadzani byli bowiem dokładnie w tajemnice wszystkich obrzędów przed przyjęciem chrztu oraz po nim, kiedy uczestniczyli jeszcze w katechezach, by ponownie uświadomić sobie to wszystko, co stało się ich udziałem. Należy dodać, że nie chodziło tutaj o czysto praktyczne nauki związane z zachowaniem się podczas samej ceremonii przyjęcia chrztu, co raczej o pokazanie głębokiej teologii i antropologii obrzędów chrzcielnych z odwołaniem się do biblijnych wydarzeń, jak i ukazaniem znaczenia poszczególnych rytów.

W miarę dokładne wiadomości na temat chrztu w Kościele IV w. czerpiemy z zachowanych katechez chrzcielnych czterech wielkich Ojców Kościoła: św. Cyryla Jerozolimskiego, św. Jana Chryzostoma, św. Ambrożego z Mediolanu oraz Teodora, biskupa Mopsuestii niedaleko Tarsu. Ostatni z nich zmarł w 428 r. i wychodzi nieco poza przyjęte przez nas ramy czasowe, dlatego tylko w niektórych przypadkach odwołamy się do jego nauki na temat chrztu. Chociaż św. Jan Chryzostom także zmarł na początku V w., bo w roku 407, to jednak posłużymy się tekstem jego katechez, gdyż głoszone były prawdopodobnie w roku 388 w Antiochii. Wspomniane pisma stanowią dla nas niezmiernie bogaty materiał źródłowy, dlatego ograniczymy się jedynie do ukazania znaczenia teologicznego oraz do wymiaru antropologicznego obrzędów chrzcielnych.

${ }^{*}$ Ks. dr hab. Bogdan Czyżewski, prof. UAM - profesor nadzwyczajny w Zakładzie Teologii Patrystycznej i historii Kościoła na Wydziale Teologicznym Uniwersytetu im. Adama Mickiewicza w Poznaniu; e-mail: czybo@amu.edu.pl.

${ }^{1} \mathrm{Na}$ temat katechumenatu i chrztu w pierwszych wiekach Kościoła zob. Katechumenat i inicjacja chrześcijańska w Kościele starożytnym, red. F. Drączkowski - J. Pałucki - P. Szczur - M. Szram - M. Wysocki - M. Ziółkowska, Lublin 2011.

${ }^{2} \mathrm{Na}$ temat historii katechumenatu godne polecenia są następujące opracowania: B. Mokrzycki, Droga chrześcijańskiego wtajemniczenia, Warszawa 1983; M. Dujarier, Krótka historia katechumenatu, tłum. A. Świeykowska - U. Grajczak, Poznań 1990; M. Murawski, Wczesnochrześcijańska katecheza, Płock 1999. 
W katechezach każdego z wymienionych autorów odnaleźć można opisy części liturgii chrzcielnej, na które składają się konkretne obrzędy. Pierwsza część to tzw. ryty przedchrzcielne, czyli wyrzeczenie się szatana, zdjęcie ubrań i namaszczenie przed chrztem ${ }^{3}$. Część druga związana była z samą kąpielą chrzcielną: przejście do basenu chrzcielnego, potrójne zanurzenie w wodzie, wyjście $\mathrm{z}$ basenu chrzcielnego, ubranie w białe szaty oraz namaszczenie.

\section{LUDZKO-BOSKI CHARAKTER RYTÓW PRZEDCHRZCIELNYCH}

Przygotowanie do chrztu zwane katechumenatem, przynajmniej w Kościele IV w., było dłuższym procesem, który trwał od dwóch do trzech lat. Był to tzw. okres wstępnego przygotowania. Bezpośrednie natomiast przygotowanie, rozpoczynało się na początku Wielkiego Postu, a na jego końcu, z soboty na Niedzielę Wielkanocna, udzielany był chrzest. Najważniejsze w tym okresie było niewątpliwie słuchanie katechez, w których wyjaśniano treści Symbolu wiary. Godnym podkreślenia elementem we wspomnianym przygotowaniu były też egzorcyzmy, którym poddawani byli katechumeni po zapisaniu się na listę oraz modlitwa w ich intencji. Nie byli to już właściwie katechumeni, ale $\varphi \omega \tau \imath \zeta o ́ \mu \varepsilon v o r$ (którzy mieli być oświeceni). Istnieją opinie, jak np. Jeana Daniélou, że od Wielkiego Postu, z chwilą zapisu imion kandydatów i po tym wszystkim, co dalej następowało, można mówić o rozpoczęciu obrzędu chrztu ${ }^{4}$. Jest $w$ tym wiele prawdy, ponieważ wystarczy przyjrzeć się obecnemu obrzędowi chrzcielnemu, który zawiera wszystkie te elementy, począwszy od pytania skierowanego do rodziców: ,Jakie imię wybraliście dla swojego dziecka?"5

Obrzędy chrzcielne, według świadectw Ojców Kościoła IV w., rozpoczynały się od wyrzeczenia się szatana i wyrażenia pragnienia przystąpienia do Chrystusa. Miały one bowiem miejsce w nocy czuwania, w Wigilię Paschalną i wchodziły w skład liturgii nocy paschalnej. Następnie mowa jest o zdjęciu ubrań i namaszczeniu olejem. Z całym przekonaniem można powiedzieć, że wymienione obrzędy stanowiły niezwykle ważny i konieczny element całej liturgii chrzcielnej w IV w., na co wskazują chociażby wielcy teologowie tego okresu, kiedy wydobywają z nich bogatą teologię.

1. Przejście od niewiary do wiary. Ryt wyrzeczenia się szatana, według przekazu św. Cyryla Jerozolimskiego, odbywał się w przedsionku baptysterium. Św. Jan Chryzostom mówi tylko o tym, że kandydaci byli prowadzeni

\footnotetext{
${ }^{3} \mathrm{Na}$ temat namaszczeń przedchrzcielnych por. G. Kretschmar, Nouvelles recherches sur l'initiation chrétienne, „La maison Dieu” (1977) nr 132, 7-32; G. Winkler, The Original Meaning of the Prebaptismal Anointing and its Implication, „Worship” 52 (1978) 24-45.

${ }^{4}$ Por. J. Daniélou, Wejście w historię zbawienia. Chrzest i bierzmowanie, thum. A. Kuryś, Kraków 1996, 15.

${ }^{5}$ Obrzędy chrztu dzieci dostosowane do zwyczajów diecezji polskich, Katowice 1987, 30.
} 
przez kapłanów ${ }^{6}$. Biskup Mediolanu - św. Ambroży wspomina, że kandydaci wchodzili do przybytku odrodzenia ${ }^{7}$, co niewątpliwie oznaczało chrzcielnicę bądź też sadzawkę chrzcielną.

Wyrzeczenie się szatana było konkretną formuła, na którą składały się gesty, słowa i ryty liturgiczne. Cyryl Jerozolimski mówi, że katechumeni zwracali się w kierunku zachodnim oraz wyciaggali rękę. Wymienione gesty posiadały swoje znaczenie teologiczne i głęboki wymiar antropologiczny. Biskup Jerozolimy thumaczy je w następujący sposób:

„Chcę wam powiedzieć, dlaczego zwróciliście się ku zachodowi. Tak trzeba. Bo zachód jest miejscem widzialnych ciemności, a szatan sam będąc ciemnością, w ciemności rządzi. Patrząc symbolicznie w stronę zachodu, odrzekliście się tego władcy mroków i ciemności”».

Cyryl podkreśla też gest wyciągniętej ręki katechumena w kierunku zachodu, co symbolizowało odrzucenie świata opanowanego przez szatana oraz zerwanie paktu, jaki wiązał człowieka z szatanem z powodu grzechu Adama9. Jan Chryzostom wspomina natomiast o uklęknięciu i wyciągnięciu rąk w kierunku nieba przez kandydatów ${ }^{10}$. Podobne świadectwo znajdujemy u Teodora z Mopsuestii, który mówi o kandydatach do chrztu, że klękają, dodaje jednak, iż mają ręce wyciaggnięte w błagalnym geście, wcześniej zaś zdejmują wierzchnie szaty ${ }^{11}$. Dla Teodora pozycja klęcząca w czasie wyrzeczenia się szatana symbolizuje najpierw niewolę, w jakiej znalazł się człowiek po upad$\mathrm{ku}$, następnie powrót do prochu ziemi na skutek służenia szatanowi. Według biskupa Mopsuestii kandydaci powstaną z klęczek i udowodnią że nie mają nic wspólnego z dawnym sposobem życia, ani też z tym, co ziemskie. Ich ręce wzniesione w górę i wzrok skierowany w niebo oznaczają nie tylko modlitwę, ale przede wszystkim błaganie, by Bóg wybawił ich z pierwotnego upadku.

${ }^{6}$ Por. Joannes Chrysostomus, Catecheses ad illuminandos 2, 18, ed. A. Wenger, SCh 50bis, Paris 1970, 143, tłum. W. Kania: Św. Jan Chryzostom, Katechezy chrzcielne (homilie katechetyczne do tych, którzy maja być oświeceni oraz neofitów), wstę i oprac. M. Starowieyski, U źródeł katechumenatu 1, Lublin 1993, 47.

${ }^{7}$ Por. Ambrosius, De mysteriis 2, 5, ed. B. Botte, SCh 25, Paris 1950, 109, thum. L. Gładyszewski, w: Św. Ambroży z Mediolanu, Wyjaśnienie symbolu; O tajemnicach; O sakramentach, ŹMT 31, Kraków 2004, 52.

${ }^{8}$ Cyrillus Hierosolymitanus, Mystagogiae 1, 4, ed. A. Piédagnel, SCh 126, Paris 1966, 88 thum. W. Kania: Cyryl Jerozolimski, Katechezy przedchrzcielne i mistagogiczne, BOK 14, Kraków 2000, 320.

${ }^{9}$ Por. Daniélou, Wejście w historię zbawienia, s. 27.

${ }^{10}$ Por. Joannes Chrysostomus, Catecheses ad illuminandos 2, 18, SCh 50bis, 143, thum. Kania, I, s. 47.

${ }^{11}$ Por. Theodorus Mopsuestenus, Homiliae catecheticae 13, 3-4. Wydanie katechez: A. Mingana: Theodore of Mopsuestia, Commentary of Theodore of Mopsuestia on the Lord's Prayer and on the Sacraments of Baptism and the Eucharist, Woodbrooke Studies 6, Cambridge 1933, 143-204; przekład fransuski: M. Debié: Théodore de Mopsueste, Homélie catéchétiques, Les Pères dans la foi 62-63, Paris 1996. 
Należy podkreślić, że gest wyciągniętej ręki bądź też rąk, posiadał swoje znaczenie w świecie starożytnym. Wykonywany był mianowicie podczas uroczystego zobowiązania, po którym następowała przysięga lub zerwanie jakiegoś zobowiązania. W przypadku chrztu oznaczał zatem zerwanie wspomnianego paktu $\mathrm{z}$ diabłem ${ }^{12}$.

Biskup Jerozolimy przytoczył też słowa, jakie towarzyszyły wspomnianemu gestowi. Katechumen mówił:

„«Odrzekam się ciebie szatanie, straszny i złośliwy tyranie». [...]. Odrzekam się ciebie, chytry i podstępny wężu. Odrzekam się ciebie, bo zastawiasz sidła. Udając przyjaźń, zrodziłeś nieprawość i namówiłeś naszych pierwszych rodziców do odstępstwa. Odrzekam się ciebie, szatanie, który jesteś sprawcą i sługą wszelkiej niegodziwości”"13.

$\mathrm{Na}$ tym jednak nie kończyła się formuła wyrzeczenia się szatana, ponieważ Cyryl wspomina o dalszych jeszcze jej częściach. Kandydat odrzekał się także „wszystkich spraw"14 szatana, do których autor katechez zalicza każdy grzech. Katechumen wypowiadał również słowa, w których odrzekał się „wszelkiej pychy” 15 szatana, czyli tzw. pompa diaboli, co dosłownie oznacza „kult bożków”" Biskup miał tutaj na myśli „szaleństwa teatralne, wyścigi konne, polowanie i tym podobne marności" ${ }^{17}$, a także wszystko, co posiadało jakikolwiek związek z kultem pogańskim ${ }^{18}$. Kandydat do chrztu mówił również do szatana, iż odrzeka się jego służby, czyli oddawania czci pogańskim bożkom poprzez zapalanie im lamp i składanie ofiar kadzenia. Do służby szatana należały też, zdaniem Cyryla, wszelkiego rodzaju praktyki magiczne: wróżenie z lotu ptaków, pytanie wyroczni, wyjaśnienia znaków, amulety, napisy na płytkach, czary ${ }^{19}$.

Św. Jan Chryzostom wspomina, że podczas obrzędu wyrzeczenia się szatana kapłan bądź też biskup ${ }^{20}$ podchodził po kolei do kandydatów i przyjmował od nich formułę wyrzeczenia:

„Potem kapłan idzie przed każdego z was i żąda zobowiązania i wyznania, każąc wam powiedzieć wstrząsające w następstwie słowa: «Odrzekam ci się,

\footnotetext{
${ }^{12}$ Por. F.J. Dölger, Die Sonne der Gerechtigkeit und die Schwarze, Münster 1919, 118-119.

${ }^{13}$ Cyrillus Hierosolymitanus, Mystagogiae 1, 4, SCh 126, 88, BOK 14, 320.

${ }^{14}$ Tamże 1, 5, SCh 126, 88, BOK 14, 320.

${ }^{15}$ Tamże 1, 6, SCh 126, 92, BOK 14, 321.

${ }^{16}$ Por. Daniélou, Wejście w historię zbawienia, s. 28.

${ }^{17}$ Cyrillus Hierosolymitanus, Mystagogiae 1, 6, SCh 126, 92, BOK 14, 321.

${ }^{18}$ Por. tamże 1, 6-8, SCh 126, 92-98, BOK 14, 321-322.

${ }^{19}$ Por. tamże 1, 7, SCh 126, 94, BOK 14, 321.

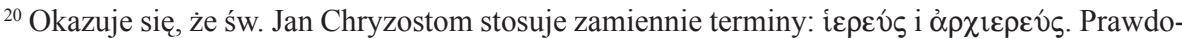
podobnie chodziło o to, że kapłani i biskupi mieli te same uprawnienia z wyjątkiem konsekracji; por. J. Pollok, Liturgia chrztu na Wschodzie $w$ drugiej połowie IV wieku na podstawie mistagogicznych homilii Cyryla Jerozolimskiego, Jana Chryzostoma i Teodora z Mopsuestii, SACh 10 (1992) 45.
} 
szatanie! [...] Odrzekam się ciebie, szatanie, odrzekam się twej pychy, twej chwały, twych spraw!»"

Teodor z Mopsuestii przekazuje treść słów, jakie towarzyszyły wyrzeczeniu się szatana:

„Wyrzekam się szatana, wszystkich jego aniołów, wszystkich jego dzieł, służby dla niego, wszystkich jego podstępów i światowych pokus"22.

Dla Teodora „,aniołami szatana” są: poeci, filozofowie, heretycy i wszyscy, którzy służą szatanowi poprzez składanie pogańskich ofiar, zajmowanie się astrologią, zachowywanie żydowskich ceremonii ${ }^{23}$. Musimy jeszcze wspomnieć o ciekawym obrzędzie występującym w liturgii syryjskiej, który kończył ryt wyrzeczenia się szatana. Otóż po otrzymaniu odpowiedzi na pytania, czy kandydat wyrzeka się szatana, biskup zmieniał strój liturgiczny, wkładał na siebie lśniąca, lnianą szatę i namaszczał czoło kandydata do chrztu. Była to tzw. pieczęć ( $\sigma \varphi \rho \alpha \gamma i \varsigma)$, która oznaczała przynależność do Chrystusa. O takim samym namaszczeniu wspomina też św. Jan Chryzostom. Należy jeszcze dodać, że po namaszczeniu czoła kandydatów rozciagano nad ich głowami lniane orarium, czyli rodzaj pasa wykonanego z lnianej tkaniny. Oznaczał on wolność, uwolnienie od ziemskich rzeczy i wybranie do służby niebiańskiej24.

Św. Ambroży z Mediolanu mówi także o wyrzeczeniu się szatana, konkretnie zaś ,jego uczynków, świata, jego swawoli i rozkoszy”25. Był to dialog prowadzony między biskupem a kandydatem do chrztu, gdzie po zadanym pytaniu padała odpowiedź: ,Wyrzekam”. Biskup Mediolanu w sposób bardzo obrazowy ukazał skutki tego wyrzeczenia, porównał je mianowicie do sytuacji, kiedy ktoś pożycza pieniądze i otrzymuje za to pokwitowanie. Ono zobowiązuje do zwrócenia zaciągniętej pożyczki. W takich okolicznościach znajduje się też ochrzczony, który winien dochować przyrzeczeń chrzcielnych ${ }^{26}$.

Dopełnieniem niejako wyrzeczenia się szatana i jego pychy ( $\alpha \pi$ ó $\tau \alpha \xi ı \varsigma$ ) był gest jemu przeciwny, mianowicie zwrócenie się kandydata na wschód, do Chrystusa ( $\sigma \hat{v} v \tau \alpha \xi ı \varsigma)$. Cyryl wyjaśnia to w następujący sposób:

„Gdy odrzekłeś się szatana, zrywając z nim wszelki układ i stare z piekłem przymierze, otwiera ci się raj boży, który uprawiał na wschodzie, a przez

${ }^{21}$ Joannes Chrysostomus, Catecheses ad illuminandos 2, 18. 20, SCh 50bis, 144-145, thum. Kania, I, s. 47-48.

${ }^{22}$ Theodorus Mopsuestenus, Homiliae catecheticae 13, 5, tłum. własne wg Debié, s. 208.

${ }^{23}$ Por. tamże 12, 10-12 (Debié, s. 211-213).

${ }^{24}$ Por. tamże 14, 1 (Debié, s. 220).

${ }^{25}$ Ambrosius, De mysteriis 2, 5, SCh 25, 109, ŹMT 31, 52.

${ }^{26}$ Por. tenże, De sacramentis I 2, 5-6, ed. B. Botte, SCh 25, 55-56, thum. L. Gładyszewski, ŹMT 31, 68-69. 
grzech został z niego wygnany nasz pierwszy ojciec. Na znak tego zwróciłeś się z zachodu na wschód, który jest krainą światła"27.

Gest ten posiadał głęboką, teologiczną i antropologiczną wymowę. Chodziło bowiem o ukazanie drugiego Adama - Chrystusa, który uwalnia człowieka spod władzy szatana i na nowo wprowadza go do raju. Dostrzegamy tutaj wyzwolenie człowieka z grzechu pierworodnego. Należy też podkreślić, że opowiedzenie się po stronie Chrystusa, czy też przystąpienie do Niego poparte było słowami: „Wierzę w Ojca i Syna i Ducha Świętego, i w jeden chrzest pokuty”28.

Św. Ambroży z Mediolanu potwierdza tę praktykę w Kościele mediolańskim, kiedy pisze w dziele $O$ tajemnicach:

„Wszedłszy więc, aby ujrzeć swego wroga, którego zamierzasz wyprzeć się w oczy, kierujesz się ku wschodowi, bo kto wyrzeka się diabła, zwraca się do Chrystusa i patrzy prosto na Niego"29.

Także św. Jan Chryzostom łączy wyrzeczenie się szatana z przejściem na służbę Chrystusa. Po pierwszym bowiem akcie katechumeni wypowiadali słowa: „Przyłączam się do Ciebie, Chrystusie!”30. Z kolei Teodor z Mopsuestii nie wspomina o zwróceniu się kandydatów z zachodu na wschód.

W związku z gestem zwrócenia się kandydata $\mathrm{w}$ kierunku wschodnim, warto jeszcze zatrzymać się na ważnym elemencie, mianowicie na pojawiającym się motywie raju. Różnie bowiem wyjaśniano użytą tutaj symbolikę wschodu. Istniał zwyczaj modlitwy chrześcijan skierowanych twarzą w kierunku wschodnim, co miało niewatpliwie odniesienie eschatologiczne, ponieważ wierzono, iż stamtąd, zgodnie z zapisem Ewangelii, przyjdzie Chrystus (por. Mt 24, 27). Wschód to także Chrystus, o czym jest mowa w Księdze Zachariasza: ,a imię jego Wschód” (Za 6, 12), a także św. Ambroży w zacytowanym powyżej zdaniu wskazał na takie rozumienie. Okazuje się jednak, że w IV w., o czym zaświadcza m.in. św. Cyryl Jerozolimski, wiązano wschód z rajem, kiedyś utraconym przez grzech, odzyskanym zaś przez chrzest. Cały zatem obrzęd wyrzeczenia się szatana i przystąpienie do Chrystusa można określić jako przejście człowieka od niewiary do wiary.

2. Zdjęcie ubrań i namaszczenie olejem. Kolejny obrzęd, który następował po wyrzeczeniu się szatana i przystąpieniu na służbę Chrystusa, odbywał się w samym baptysterium. Najpierw miało miejsce zdjęcie ubrań kandydatów do chrztu. Oznaczało ono odrzucenie starego człowieka z tym wszystkim, co się z nim wiązało. Należało porzucić dotychczasowe życie i podjąć

\footnotetext{
${ }^{27}$ Cyrillus Hierosolymitanus, Mystagogiae 1, 9, SCh 126, 98, BOK 14, 322.

${ }^{28}$ Tamże.

${ }^{29}$ Ambrosius, De mysteriis 2, 7, SCh 25, 109, ŹMT 31, 52.

${ }^{30}$ Joannes Chrysostomus, Catecheses ad illuminandos 2, 21, SCh 50bis, 145, thum. Kania, I, s. 48.
} 
nowe ${ }^{31}$. Symboliczna była też nagość kandydatów, o czym mówił do neofitów św. Cyryl Jerozolimski:

„Rozebrani z szat byliście nadzy - na wzór Chrystusa nagiego na krzyżu, który przez swoją nagość, rozbroiwszy księstwa i moce, odniósł nad nimi jawnie triumf na drzewie" ${ }^{\prime 2}$.

Cyryl wspomina Chrystusa, który wisiał nagi na krzyżu, przez co pokonał szatana. Biskup nawiązuje też do nagości Adama w raju, który, podobnie jak katechumeni, nie odczuwał z tego powodu żadnego wstydu ${ }^{33}$. Wyzbycie się zatem starego ubrania to nie tylko porzucenie poprzedniego, grzesznego stylu życia, ale również zanik wstydu grzesznego człowieka przed Panem Bogiem i odzyskanie tego, co było przywilejem człowieka w raju, mianowicie synowskiej ufności - uczucia przeciwnego wstydowi ${ }^{34}$.

Także św. Jan Chryzostom szczegółowo omawia symbolikę zdjętych szat i włożenia nowych przez kandydata do chrztu. Stara szata to złe i grzeszne życie, dlatego należy ją zdjąć przed wejściem do basenu chrzcielnego:

„zdejmujemy stare szaty zbrudzone grzechami, i wdziewamy nowe, oczyszczone z wielkiej skazy"35.

Teodor z Mopsuestii również wspomina o wyzbyciu się swojego odzienia, które jest znakiem śmiertelności. Odwołuje się nawet do Rdz 3,21, gdzie jest mowa o śmiertelności symbolizowanej przez „odzienie ze skór”, które nosili nasi prarodzice po popełnieniu grzechu. Według Teodora było ono:

„znakiem śmiertelności i znakiem potępiającego wyroku [Bożego], przez który zostaliście zobowiązani do noszenia okrycia"36.

Następnym obrzędem, na który zwracają uwagę autorzy katechez chrzcielnych, jest namaszczenie ${ }^{37}$. Rozpoczynał je biskup, kończył zaś kapłan lub diakon w przypadku mężczyzn, w odniesieniu zaś do kobiet czynność tę wykonywała diakonisa ${ }^{38}$. Cyryl pisze o namaszczeniu w następujący sposób:

${ }^{31}$ Por. T. Kaczmarek, Ryty chrzcielne jako naśladowanie tajemnic paschalnych wedlug II katechezy mistagogicznej Cyryla Jerozolimskiego, VoxP 10 (1990) t. 18, 84.

${ }^{32}$ Cyrillus Hierosolymitanus, Mystagogiae 2, 2, SCh 126, 106, BOK 14, 325.

${ }^{33}$ Por. tamże.

${ }^{34}$ Por. Daniélou, Wejście w historię zbawienia, s. 43.

${ }^{35}$ Joannes Chrysostomus, Catecheses ad illuminandos 2, 11, SCh 50bis, 139, thum. Kania, I, s. 45.

${ }^{36}$ Theodorus Mopsuestenus, Homiliae catecheticae 14, 8, tłum. własne wg Debié, s. 225.

${ }^{37}$ Warto wspomnieć tutaj o ciekawym opracowaniu P. Szczura (Rola zmystów wiary w zrozumieniu sakramentów inicjacji chrześcijańskiej wedlug Cyryla Jerozolimskiego, VoxP 34 (2014) t. 61, 297-308) na temat fizycznych i duchowych zmysłów, na które zwraca uwagę w swoich katechezach mistagogicznych św. Cyryl Jerozolimski. Biskup posługiwał się różnego rodzaju szczegółami wizualnymi, by bardziej zaangażować neofitów w przeżywanie sakramentów inicjacji chrześcijańskiej.

${ }^{38}$ Por. K. Werbel, Św. Cyryl Jerozolimski jako katecheta, Poznań 1934, 64; B. Czyżewski, Diakoni i diakonise wedtug ,,Konstytucji apostolskich”, SG 23 (2009) 79-94. 
„Rozebranych z szat namaszczono was poświęconym olejem od głowy aż do stóp. Staliście się przez to uczestnikami szlachetnej oliwki, Jezusa Chrystusa. Odcięci bowiem od dzikiego drzewa oliwnego zostaliście zaszczepieni na szlachetnej oliwce, aby uczestniczyć w tłustości prawdziwej oliwki. Poświęcony olej oznacza łączność z tłustością Chrystusa, który usunął wszelki ślad wrogiej mocy. Jak bowiem tchnienie na świętych i wezwanie imienia Bożego jak najmocniejszy ogień pali i wypędza szatanów, tak i ten poświęcony olej po wezwaniu Boga i po modlitwie otrzymuje tak wielką siłę, że nie tylko wypala ślady grzechów, lecz nawet wszelkie niewidzialne złe moce zmusza do ucieczki" ${ }^{\prime 39}$.

Z powyższego tekstu wynika, że w obrzędzie namaszczenia można dostrzec trzy ważne motywy. Pierwszy to uzdrowienie. Olej używany do namaszczenia nazywany był olejem egzorcyzmów, co miało spowodować oczyszczenie i uzdrowienie. Drugi motyw związany był z koniecznością podjęcia walki ze złem. Poświęcony olej nie daje szatanowi przystępu do człowieka. Wreszcie trzeci motyw, na jaki wskazuje św. Cyryl w związku z namaszczeniem, posiada wymiar chrystologiczny. Namaszczony zostaje bowiem włączony w życie Chrystusa, co obrazowo przedstawił św. Paweł, a powołuje się na ten przykład św. Cyryl, mówiąc o wszczepieniu w szlachetne drzewo oliwne (por. Rz 11, 17-24) ${ }^{40}$.

Bardzo podobne aspekty odnaleźć można u św. Jana Chryzostoma, który wspomina o dwóch namaszczeniach przedchrzcielnych. Pierwsze było namaszczeniem „na czole duchowym olejem” ${ }^{41} \mathrm{w}$ imię Trójcy, drugie natomiast polegało na namaszczeniu całego ciała duchową oliwa, by wzmocnić je i zabezpieczyć przed atakami szatana ${ }^{42}$. Motyw obrony i podjęcia walki przedstawia biskup Konstantynopola posługując się metaforą atlety, który przed walką jest namaszczany oliwa, by przeciwnik nie miał do niego łatwego dostępu ${ }^{43}$. Namaszczenie to wzmacnia do walki z szatanem i stanowi powłokę ochronną przed wszelkimi wrogami ${ }^{44}$. Należy też zaznaczyć, że św. Jan Chryzostom namaszczenia nie wiąże z darem Ducha Świętego. Według niego zstąpienie Ducha Świętego następuje podczas kąpieli chrzcielnej ${ }^{45}$.

\footnotetext{
${ }^{39}$ Cyrillus Hierosolymitanus, Mystagogiae 2, 3, SCh 126, 106 i 108, BOK 14, 325-326.

${ }^{40}$ Por. tamże.

${ }^{41}$ Joannes Chrysostomus, Catecheses ad illuminandos 2, 24, SCh 50bis, 147, thum. Kania, I, s. 49.

${ }^{42}$ Por. tamże 2, 22, SCh 50bis, 145-146, thum. Kania, I, s. 48-49.

${ }^{43}$ Por. tamże 3, 8-11, SCh 50bis, 155-158, tłum. Kania, I, s. 55-56.

${ }^{44}$ Por. J. Daniélou, Symbolika obrzędów chrzcielnych, Kraków 1998, 46.

${ }^{45}$ Joannes Chrysostomus, Catecheses ad illuminandos 2, 25, SCh 50bis, 147, tłum. Kania, I, s. 49. Niektórzy uważają, że świadectwo Jana Chryzostoma wskazuje, iż chrzest i bierzmowanie były udzielane równocześnie (por. L. C. Mitchell, Baptismal Anointing, London 1966, 39).
} 


\section{ANTROPOCENTRYZM I TEOCENTRYZM KĄPIELI CHRZCIELNEJ}

Dalsze elementy obrzędów chrzcielnych, w których występuje interesująca teologia chrzcielna i antropologiczny charakter tego sakramentu, to przede wszystkim przejście kandydatów do basenu chrzcielnego, zanurzenie w wodzie i w końcu ubranie w białe szaty, których kolor miał symboliczne i głębokie znaczenie. Za ostatni element chrztu uznać można pochrzcielne namaszczenie.

1. Przejście do basenu chrzcielnego i zanurzenie w wodzie. Ważnym i pełnym symboliki gestem było bez wątpienia przejście kandydatów do basenu chrzcielnego. Sw. Cyryl Jerozolimski porównuje je do zdjęcia ciała Chrystusa z krzyża i przeniesienia go do grobu ${ }^{46}$. Mamy zatem tutaj wydźwięk chrystologiczny tego obrzędu. Katechumen przechodził do sadzawki chrzcielnej, która symbolicznie stawała się grobem dla jego grzechów. Grób to także miejsce oczekiwania na zmartwychwstanie.

Najważniejszym jednak obrzędem w całej ceremonii chrzcielnej było potrójne zanurzenie w uprzednio poświęconej już wodzie. Zanim to nastąpiło, kandydaci musieli jeszcze wyznać wiarę. Każdy z nich zapytany został, „czy wierzy w imię Ojca i Syna, i Ducha Świętego" "47. Potem następowało trzykrotne zanurzenie w wodzie i wynurzenie się z niej. Cyryl dostrzega w tym geście analogię do złożenia ciała Chrystusa na trzy dni i trzy noce do wnętrza ziemi:

„Po wyznaniu zbawczej wiary zanurzyliście się trzykroć w wodzie i wynurzyliście się - zaznaczając w tym trzydniowy pobyt Chrystusa w grobie. Jak bowiem nasz Zbawiciel przebywał trzy dni i trzy noce w łonie ziemi, tak i wy w pierwszym wyjściu z wody naśladowaliście pierwszy dzień Chrystusa w ziemi i noc w zanurzeniu"48.

Św. Ambroży z Mediolanu także wspomina o wyznaniu wiary przed samym aktem zanurzenia w wodach chrzcielnych:

„Zapytano cię: «Czy wierzysz w Boga Ojca wszechmogącego?» Powiedziałeś: «Wierzę» i zanurzyłeś się, to znaczy pogrzebano cię. Ponownie zapytano: «Czy wierzysz w Pana naszego Jezusa Chrystusa i w Jego krzyż?» Powiedziałeś: «Wierzę» i zanurzyłeś się. Zostałeś więc również współpogrzebany z Chrystusem. A kto razem z Chrystusem zostaje pogrzebany, razem z Nim zmartwychwstaje. Po raz trzeci zapytano: «Czy wierzysz w Ducha Świętego?» Powiedziałeś: «Wierzę» i zanurzyłeś się po raz trzeci, aby trzykrotne wyznanie wiary usunęło wielokrotne w życiu dotychczasowym popełniane grzechy" ${ }^{49}$.

\footnotetext{
${ }^{46}$ Por. Cyrillus Hierosolymitanus, Mystagogiae 2, 4, SCh 126, 110, BOK 14, 326.

${ }^{47}$ Tamże.

${ }^{48}$ Tamże.

${ }^{49}$ Ambrosius, De sacramentis II 7, 20, SCh 25, 68, ŹMT 31, 77.
} 
Powyższe gesty posiadały głęboką symbolikę. Zanurzenie oznaczało bowiem śmierć dla grzechu, wynurzenie zaś nowe narodzenie, zmartwychwstanie, co poświadczają autorzy analizowanych katechez chrzcielnych z IV wieku. Mowa jest o tym, że chrzest jest antytypem męki i zmartwychwstania, co oznacza, że jest i podobny, i zarazem odmienny od męki i zmartwychwstania. Doskonale wyjaśnia tę prawdę św. Ambroży z Mediolanu, który pisze:

„Apostoł mówi, jak słyszeliście w dzisiejszym czytaniu, że każdy kto otrzymuje chrzest, przyjmuje go w śmierci Jezusa (por. Rz 6, 3). Co to oznacza w śmierci? Podobnie jak Chrystus umarł, tak i ty masz zakosztować śmierci (por. Rz 6, 10; Mt 16, 28 itp.); podobnie jak Chrystus umarł dla grzechu, a żyje dla Boga, tak i ty masz poprzez sakrament chrztu umrzeć dla dawnych grzesznych ponęt i zmartwychwstać dzięki łasce Chrystusowej. Jest to więc śmierć, ale nie prawdziwa śmierć cielesna, lecz tylko jej podobieństwo. Gdy się zanurzasz, wówczas dzieje się coś, co przypomina śmierć i pogrzeb. Otrzymujesz sakrament Krzyża, ponieważ Chrystus zawisł na krzyżu, a Jego Ciało zostało przebite gwoźdźmi. Ty więc jesteś współukrzyżowany, połączony z Chrystusem, przytrzymują cię gwoździe Pana naszego Jezusa Chrystusa, aby szatan nie mógł ciebie oderwać. Oby przytrzymywał cię gwóźdź Chrystusowy, mimo że go wyrywa słabość ludzkiej natury"so.

Wyróżniony zatem zostaje podwójny aspekt w męce i śmierci Chrystusa: cielesny i duchowy. Chodzi mianowicie o rzeczywistość historyczna, która w obrzędzie chrztu jest symbolizowana i przedstawiana oraz o treść zbawczą obejmująca rzeczywiste uczestnictwo ${ }^{51}$. Warto podkreślić też fakt, iż przechodzenie kandydatów przez sadzawkę chrzcielną kojarzyło się Ambrożemu z przejściem Izraelitów przez Morze Czerwone. Dlatego też interpretuje to jako paschę, przejście (transitus)

„od rzeczy ziemskich do niebieskich, [...] od grzechu do życia, od winy do łaski, od nieprawości do uświęcenia - kto przechodzi przez to źródło, nie umiera, lecz zmartwychwstaje" ${ }^{2}$.

Św. Jan Chryzostom kieruje uwagę słuchaczy na kapiel chrzcielną. Nowością, w porównaniu z innymi autorami tego okresu, jest niewątpliwie formuła chrzcielna, która brzmi: „Jest on ochrzczony w imię Ojca i Syna, i Ducha Świętego" "53. Prawdopodobnie chodziło Chryzostomowi o to, by w toczącej się ciągle polemice $\mathrm{z}$ arianami podkreślić jedność bóstwa trzech Osób Bożych, o czym zaświadcza biskup Konstantynopola, kiedy zwracając się do neofitów

\footnotetext{
${ }^{50}$ Tamże II 7, 23, SCh 25, 69, ŹMT 31, 78.

${ }^{51}$ Por. Daniélou, Wejście w historię zbawienia, s. 51-52.

${ }^{52}$ Ambrosius, De sacramentis I 4, 12, SCh 25, 58, ŹMT 31, 70.

${ }^{53}$ Joannes Chrysostomus, Catecheses ad illuminandos 2, 26, SCh 50bis, 147, thum. Kania, I, s. 49.
} 
mówi, że chrzest jest sprawowany w taki sposób, ,,abyś widział [...], iż Ojciec, Syn i Duch Święty są jedną istotą" ${ }^{54}$.

Ciekawe są także u Jana Chryzostoma metafory podstawowego aktu liturgii chrzcielnej. Pierwsza i druga odnosi się do wejścia katechumena do basenu chrzcielnego i wyjścia z niego. Wejście oznacza śmierć starego człowieka, wyjście natomiast to zmartwychwstanie człowieka nowego, odnowionego na obraz Stwórcy ${ }^{55}$. Biskup Konstantynopola mówiąc o śmierci starego człowieka w chrzcie, posługuje się obrazami, co było zrozumiałe, ponieważ swoje słowa kierował do neofitów, dla których obraz przeżytego niedawno chrztu mocno utrwalił się w ich pamięci. Dlatego za św. Pawłem zachęcał nowoochrzczonych, by raz umarli grzechowi nie mieli nic wspólnego z namiętnościami ciała i ze sprawami ziemi ${ }^{56}$. Punktem odniesienia jest oczywiście dla Chryzostoma Chrystus, który umarł i zmartwychwstał:

„Chrzest jest pogrzebem i zmartwychwstaniem. «Stary człowiek pogrzebany jest z grzechem i nowy człowiek wstaje, odnowiony na obraz Tego, który go stworzył» $(\mathrm{Kol} 3,10))^{\prime 57}$.

Trzecia metafora, jaką posługuje się biskup Jan, związana jest z użytym przez św. Pawła określeniem: „kąpiel odrodzenia” (por. Tt 3, 5). Odrodzenie to wynik odpuszczenia grzechów, a kąpiel w wodzie jest potrzebna, by oczyścić i umyć ciało. Staje się to możliwe dzięki ukrzyżowanemu Chrystusowi, którego bok został przebity włócznią żołnierza i wówczas wypłynęły z niego krew i woda. One też spływają do basenu chrzcielnego, powodując oczyszczenie i odrodzenie. Co więcej, kandydaci do chrztu zrodzeni są z boku ,śpiącego" na krzyżu Chrystusa, podobnie jak Ewa została zrodzona z boku śpiącego Adama $^{58}$. Jest to wyjaśnienie $\mathrm{z}$ pewnością oryginalne i niespotykane u innych Ojców Kościoła.

Cyryl zwraca też uwagę na skutki chrztu, mówi mianowicie o odpuszczeniu grzechów, o usynowieniu i o otrzymaniu daru Ducha Świętego ${ }^{59}$.

2. Symbol białej szaty. Warto zwrócić uwagę na jeszcze jeden obrzęd, który następował po wyjściu ochrzczonego z wody. Ubierał się on w biała szatę. Św. Ambroży wyjaśnia jego znaczenie w następujący sposób:

„Potem otrzymałeś biały strój na znak, że zdjąłeś okrycie grzechów, a przybrałeś czyste szaty niewinności”" ${ }^{\prime 0}$.

\footnotetext{
${ }^{54}$ Tamże.

${ }^{55}$ Por. tamże 2, 25, SCh 50bis, 147, tłum. Kania, I, s. 49.

${ }^{56}$ Por. tamże 7, 22, SCh 50bis, 240, tłum. Kania, I, s. 104.

${ }^{57}$ Tamże 2, 11, SCh 50bis, 139, thum. Kania, I, s. 44.

${ }^{58}$ Por. tamże 3, 16-17, SCh 50bis, 160-161, thum. Kania, I, s. 57-58.

${ }^{59}$ Por. Cyrillus Hierosolymitanus, Mystagogiae 2, 6, SCh 126, 114 i 116, BOK 14, 327.

${ }^{60}$ Ambrosius, De mysteriis 7, 34, SCh 25, 118, ŹMT 31, 59.
} 
Biskup Mediolanu posługuje się tutaj obrazem białej szaty, by podkreślić jeden z aspektów łaski chrztu, mianowicie czystość duszy.

Także św. Cyryl Jerozolimski zwraca uwagę na białe szaty ochrzczonych, które są znakiem czystości ich duszy:

„Skoro zdjąłeś stare szaty i wdziałeś duchowe, białe, winny one pozostać zawsze białe. Nie znaczy to, iż zawsze trzeba nosić szaty białe, powinny jednak one zostać prawdziwie białe, jasne i duchowe, abyś mógł powiedzieć z błogosławionym Izajaszem: «Raduje się dusza moja w Panu, albowiem mnie okrył szatą zbawienia i płaszczem nadziei» (Iz 61, 10)"61.

Jan Chryzostom nie wspomina o obrzędzie przywdziania przez nowoochrzczonych białych szat, mówi jedynie, że przyoblekli się w Chrystusa, chociaż „przebywają na ziemi, wyglądają jak aniołowie, lśniąc jak promienie słońca" "2. Tę wypowiedź można z pewnością uznać za ocenę nie tylko duszy ochrzczonych, ale też ich zewnętrznego wyglądu - ubrani w białe szaty przypominali ludzi nieskazitelnych i czystych, podobnych do aniołów.

3. Namaszczenia pochrzcielne. Ostatnim elementem rytu chrzcielnego było namaszczenie ${ }^{63}$. Budzi ono wiele dyskusji, ponieważ nie wszyscy wymieniani tutaj autorzy o nim wspominają. Pochrzcielnego namaszczenia nie zna św. Jan Chryzostom. Wspomina natomiast o nim św. Cyryl Jerozolimski, który rozbudowuje je i uzasadnia. Biskup Jerozolimy mówi mianowicie o namaszczeniu czoła, nosa, uszu i klatki piersiowej:

„Najpierw namaszczano was na czole, abyście wolni byli od wstydu, z którym chodził wszędzie pierwszy grzeszny człowiek, i odsłoniętą twarzą jak w zwierciadle odbijali chwałę Pańską (por. 2Kor 3, 18). Następnie na uszach, abyście otrzymali uszy, które słuchają bożych tajemnic, uszy, o których powiedział Izajasz: «I dał mi Pan ucho do słuchania» (Iz 50,4), i Pan Jezus w Ewangelii: «Kto ma uszy, niech słucha!» (Mt 11, 15). Potem na nozdrzach, abyście po przyjęciu Boskiej oliwy mówili: «Jesteśmy wonnością Chrystusa dla Boga między tymi, którzy idą na zbawienie» (2Kor 2, 15). Wreszcie na piersiach, abyście «przyodziani w pancerz sprawiedliwości, stawili śmiało czoła szatańskim zakusom» (Ef 6, 11. 14)" ${ }^{\prime 64}$.

Św. Cyryl zwraca uwagę w tym tekście na obrzęd bierzmowania, w czasie którego neofita otrzymywał moc Ducha Świętego. Biskup celowo posługuje się różnego rodzaju tekstami biblijnymi, by pokazać możliwość odbierania

\footnotetext{
${ }^{61}$ Cyrillus Hierosolymitanus, Mystagogiae 4, 8, SCh 126, 142 i 144, BOK 14, 337.

${ }^{62}$ Joannes Chrysostomus, Catecheses ad illuminandos 2, 27, SCh 50bis, 149, thum. Kania, I, s. 50.

${ }^{63} \mathrm{Na}$ temat namaszczeń w sakramentach inicjacji chrześcijańskiej por. P. Nowakowski, Duch Święty w inicjacji chrześcijańskiej - obrzęd namaszczenia krzyżmem we wschodniej tradycji liturgicznej pierwszych wieków, „Liturgia Sacra” 4 (1998) fasc.1, 39-48.

${ }^{64}$ Cyrillus Hierosolymitanus, Mystagogiae 3, 4, SCh 126, 126, BOK 14, 332.
} 
przez ochrzczonego różnego rodzaju zmysłami duchowymi nadprzyrodzonych rzeczywistości ${ }^{65}$.

Wzmiankę na temat namaszczenia czoła po chrzcie spotykamy także u Teodora $\mathrm{z}$ Mopsuestii ${ }^{66}$, chociaż należy przyznać, że poświęca mu mniej uwagi niż Cyryl Jerozolimski. Biskup Mopsuestii nie mówi jasno o namaszczeniu ( $\left.\sigma \varphi \rho \alpha \gamma^{\prime} \varsigma\right)$, tak jak w przypadku namaszczenia przedchrzcielnego, ale o „,naznaczeniu”. Druga trudność, czy uznać to „naznaczenie” za „namaszczenie” wynika z tego, że w liturgii syryjskiej najstarsze świadectwo o namaszczeniu pochrzcielnym pochodzi z Konstytucji Apostolskich, których powstanie datuje się na rok 380 lub 381. Nie łączą one jednak tego namaszczenia z udzieleniem daru Ducha Świętego. Dopiero na przełomie V i VI w. Pseudo-Dionizy Areopagita wyraźnie poświadcza istnienie w liturgii syryjskiej pochrzcielnego namaszczenia, które jest równoznaczne z udzieleniem Ducha Swiętego ochrzczonemu ${ }^{67}$.

Biskup Mediolanu - Ambroży umieszcza obrzęd namaszczenia po wyjściu ochrzczonego $\mathrm{z}$ wody. Było to prawdopodobnie obfite polanie głowy olejem ${ }^{68}$. Nie można jednak identyfikować tego namaszczenia z bierzmowaniem, chodziło tutaj o namaszczenie na życie wieczne, o zapowiedź wieczności i zmartwychwstania ${ }^{69}$. Chociaż Ambroży podkreśla w swoich katechezach działanie Ducha Świętego w duszy człowieka, nie wspomina jednak o tym, że przez akt chrztu udzielony zostaje Duch Święty, łączy go raczej z rytem, który następował po chrzcie ${ }^{70}$.

Podsumowując dotychczasowe rozważania należy powiedzieć, że interpretacja poszczególnych obrzędów chrzcielnych u pisarzy Kościoła IV w. szła w dwóch kierunkach: teologicznym i antropologicznym. Oznacza to, że dostrzegali oni i doceniali jeden i drugi wymiar tego sakramentu. Można też mówić o wyraźnej spójności w odniesieniu do tych dwóch elementów. Jeżeli nawet istniały jakieś różnice u poszczególnych autorów katechez w opisie niektórych rytów chrzcielnych, nie dotyczyły one tego, co istotne, mianowicie rozumienia samego chrztu oraz znaczenia zawartych w nim obrzędów. Każdy z mistagogów zwraca uwagę na wymiar antropologiczny obecny w obrzędach chrzcielnych i głęboki ich charakter duchowy. W ten sposób to, co ludzkie w tym sakramencie, pozwalało dostrzec element boski i zbudować bogata

${ }^{65}$ Por. Szczur, Rola zmystów wiary, s. 302.

${ }^{66}$ Por. Theodorus Mopsuestenus, Homiliae catecheticae 14, 27 (Debié, s. 239).

${ }^{67}$ Por. Pseudo-Dionysius Areopagita, De ecclesiastica hierarchia 2, PG 3, 392 ${ }^{\circ}-404 \mathrm{D}$, thum. M. Dzielska, w: Pseudo-Dionizy Areopagita, Pisma teologiczne, Kraków 2005, 145-155; 4, PG 3 , 472D - 485B, thum. Dzielska, s. 174-183.

${ }^{68}$ Por. Ambrosius, De mysteriis 6, 29, SCh 25, 117, ŹMT 31, 58.

${ }^{69}$ Por. tamże.

${ }^{70}$ Por. L. Gładyszewski, Wstęp, w: ŹMT 31, 34-35. 
teologię każdego z elementów liturgii chrzcielnej. Nie wolno zapominać, że autorzy katechez zawsze sytuują w sakramencie chrztu zarówno Boga, jak i człowieka, który otrzymuje godność dziecka Bożego. Dlatego też wolno powiedzieć, iż cały obrzęd chrzcielny, zwłaszcza zaś kąpiel chrzcielna, posiadają wymiar teocentryczny i antropocentryczny. Sercem chrztu jest bowiem Bóg, który jest dawcą tego sakramentu i człowiek będący odbiorcą wszelkich łask z nim związanych.

Z całą też pewnością można powiedzieć, że zauważalny wszędzie w katechezach wymiar teologiczny i antropologiczny obrzędów chrzcielnych, został przez Ojców IV w. przedstawiony w oparciu o odwoływanie się do tradycji biblijnej. Zastosowana typologia, porównania z Chrystusem, ze stanem człowieka po grzechu i przed chrztem, dawały podstawę do ukazania zbawczego charakteru tego sakramentu a także stały się podstawą refleksji trynitarnej i chrystologicznej.

Należy również podkreślić dobre przygotowanie kandydatów do chrztu dzięki wcześniejszej katechezie oraz poprzez naukę mistagogiczną, jaka miała miejsce po przyjęciu chrztu i kierowana była już do neofitów. Dzięki temu, przyjmowanie i przeżywanie tajemnicy chrztu przez chrześcijan, było niewątpliwie pogłębione i świadome.

\section{THEOLOGICAL AND ANTHROPOLOGICAL SIGNIFICANCE OF BAPTISMAL RITES IN CHURCH OF THE $4{ }^{\mathrm{TH}}$ CENTURY}

\section{(Summary)}

The Holy Baptism in Church in period of the first centuries was considered as an extra ordinary and important event, both in life of the baptized person, as well as in the entire Church community. Almost exact information on baptism in Church of the $4^{\text {th }}$ century is available in existing documents of empathetical discourses on baptism by four great Fathers of the Church: St. Cyril of Jerusalem, St. John Chrysostom, St. Ambrose of Milan, and Theodor, bishop of Mopsuestia. Thus in this paper I have decided to present only the Baptismal Rites and their theological and anthropological significance. In terms of the mentioned authors' writings, we can find two parts of the baptismal liturgy where they consist of particular Rites. The first part is devoted to so called the rites preceding a ceremony of baptism, It means to surrender Satan, take off cloths and apply the holy oil before one's baptism. Another Rite, i.e. taking off clothes of the candidates to be baptized, was significant for the new way of life of a certain human being, and rejection of the old man with his all affairs and matters. Authors of baptismal discourses also paid their attention to application of the holy oil. The second part of Baptismal Rites was related to baptismal immersion itself. First of all, there was the following order: to reach the baptismal tank, immerse in waters three times, then leave it and put on the white clothes. The theological interpretation of particular Baptismal 
Rites in writings of the Church of the $4^{\text {th }}$ century was rather compact. Even in case of some differences available, they were not concerned with the principal aspects, but strictly devoted to the baptism itself in order to understand the ceremony, and all particular order of the Baptismal Rites.

Key words: Holy Baptism, Baptismal Rites, Cyril of Jerusalem, John Chrysostom, Ambrose of Milan, Theodor Mopsuestia, theological, anthropological.

Słowa kluczowe: chrzest św., ryty chrzcielne, Cyryl Jerozolimski, Jan Chryzostom, Ambroży z Mediolanu, Teodor z Mopsuestii, teologiczny, antropologiczny. 
